\title{
Storage Stability of Germinated Brown Rice Incorporated Baked Products
}

\author{
B. Mounika ${ }^{1}$, S. Suchiritha Devi ${ }^{1 *}$, K. Uma Maheswari ${ }^{1}$ and V. Hemalatha ${ }^{2}$ \\ ${ }^{1}$ Department of Foods and Nutrition, Professor Jayashankar Telangana State Agricultural \\ University, Rajendranagar, Hyderabad - 500 030, Telangana, India \\ ${ }^{2}$ Department of Genetics and Plant Breeding, College of Agriculture, Professor Jayashankar \\ Telangana State Agricultural University, Rajendranagar, Hyderabad - 500 030, Telangana, India \\ *Corresponding author
}

\section{Keywords}

Germinated brown rice, Shelf life, Microbial analysis.

Article Info

Accepted:

28 November 2017

Available Online:

10 December 2017
A B S T R A C T

Shelf life studies of food products are gaining impetus due to the consumer awareness towards quality of the ready to cook products. The present study was designed to assess the storage stability of germinated brown rice incorporated baked products. The developed cookies with $10 \%$ GBR and $20 \%$ GBR of muffins were stored for 6 days. There was a decreasing trend of sensory scores for colour, texture, taste, flavour, and overall acceptability for selected bakery products, during shelf life study. An increase in free fatty acid content levels with storage was observed in cookies and muffins. In cookies the bacteria colonies were observed in $15^{\text {th }}$ and $30^{\text {th }}$ days. The fungi were observed on the $30^{\text {th }}$ day of storage in cookies.

\section{Introduction}

The requirement for highly nutritious food is escalating because of the commercial opportunity offered by such products, increasing consumer consciousness of the relationship between food and health, and the extensive industrial use for nutrient supplementation, pharmaceutical purposes, food additives and animal feeds.

With the changing life styles and increased disposable income in advanced countries has led to an increase in demand for processed foods. Development of fortified biscuits or other composite flour bakery products is the latest trend in bakery industry (Obradović et al., 2015). Roy et al., (2011) stated that as rice is the staple food for nearly two-thirds of the world's population, the food components and environmental load of rice depends on the rice form due to different processing conditions. Brown rice, germinated brown rice and partially milled rice contain health beneficial food components compared to well milled rice.

Ilowefah et al., (2014) showed that as fermentation could reduce the negative effects of bran on final cereal products, the utilization 
of whole-cereal flour is recommended, such as brown rice flour as a functional food ingredient. Those individuals live with Celiac disease are not able to eat many baked products, specifically cookies made with wheat flour because wheat contain gluten. By totally substituting all-purpose flour with brown rice flour, those with celiac disease are able to consume the cookie. Brown flour also offers more health benefits than all-purpose flour. The cookie seemed to have little difference in colour and texture when compared to the control cookie (Khuns and coulter 2009). Therefore present study was planned to analyse the shelf life and microbial study of brown rice incorporated baked products.

\section{Materials and Methods}

Paddy (Oryza sativa) variety RNR 15048 were procured from Rice section, ARI Rajendranagar, Hyderabad. Raw materials required for baked products development were procured from the local market, Hyderabad. Preparation of geminated brown rice powder as per the procedure given by Mounika et al., (2016). Cookies and muffins were prepared as per the standard procedures.

Cookies were stored up to 30 days whereas the other products muffins were stored up to 6 days. The details of sensory quality changes during storage were observed at every fifteen days intervals for cookies and 3 days intervals for muffins. Each product was stored in high density polythene food grade pouches for further analysis. A semi-trained panel of 15 members using 9 point hedonic scale from PGRC, PJTSAU evaluated the products for colour, texture, flavour, taste and overall acceptability for stored products. Free fatty acids of the developed baked products were analysed as per AOCS 1990. Microbial quality of the developed products were analysed as per the procedure given by (Thambekar et al., 2009). All the result will be statistically analyzed to test the significance of the results using percentages, means, standard deviations and analysis of variance (ANOVA) technique (Snedecor and Cochran, 1983).

\section{Results and Discussion}

\section{Mean sensory scores after storage of} cookies

The results obtained showed that 10\% GBR incorporated cookies rated with highest acceptability among those three variations $(10 \%, 20 \%$ and $30 \%)$. On the initial day, the samples recorded high scores for all parameters evaluated i.e., color, texture, taste, flavor and overall acceptability (7.40).

However, the profile changed considerably after 15 days of storage (overall acceptability $7)$. There was a significant decrease $(p<0.05)$ in the sensory characteristics of cookies after $30^{\text {th }}$ day of storage (acceptability 6.5). The results showed that the cookies can be stored up to 30 days at room temperatures. The results of the mean sensory evaluation of cookies from initial day to end of storage period are presented in the table 1 .

\section{Mean sensory scores after storage of muffins}

The 20\% GBR incorporated muffins are selected as the best variation according to sensory evaluation. These muffins are also stored for 6 days same as nankhatai because muffins have the smooth texture it will become very hard when stored for longer period. Sensory evaluation is held on $3^{\text {rd }}$ and $6^{\text {th }}$ day of storage period. The result shows that muffins can be stored for 6 days. Acceptability of muffins at initial day was 7.9 after 3 days acceptability was reduced to 7.1. Acceptability score of muffins after 6days of storage was 6.5. Statistically, significant difference was observed in between initial 
day and $3^{\text {rd }}$ day. The results of sensory evaluation presented in figure 1 .

\section{Free fatty acid content of baked products}

The fat components of a bakery fat must thus be selected with regard to the storing conditions and desired shelf-life for the finished product (Baljit et al., 2002). However, it is important to know that how much the oxidative stability has changed throughout shelf-life of these products for both consumer health and product quality. Because long storage times may be involved between preparation and consumption of the foodstuff. Cookies were subjected to free fatty acid estimation on different storage intervals that is at 0 days, 15 days and 30 days, the results are depicted in Table 2. Similarly muffins were subjected to free fatty acid estimation on storage interval of 0 day, 3 days and 6 days (Table 3). An increase in free fatty acid content levels with storage was observed in cookies and muffins. Free fatty acid content for cookies ranged between $0.53 \pm 0.02$ to $0.72 \pm 0.02$. Free fatty acid content of muffins ranged from $0.45 \pm 0.03$ to $0.63 \pm 0.02$. Statistically significant difference was observed in free fatty acid content of cookies during the storage period.

Table.1 Mean sensory scores after storage of cookies

\begin{tabular}{|l|l|l|l|l|l|}
\hline Storage period & Color & Texture & Taste & Flavor & Overall acceptability \\
\hline $0^{\text {th }}$ day & $7.70^{\mathrm{a}} \pm 0.82$ & $7.80^{\mathrm{a}} \pm 0.42$ & $7.60^{\mathrm{a}} \pm 0.70$ & $7.60^{\mathrm{a}} \pm 0.70$ & $7.40^{\mathrm{a}} \pm 0.52$ \\
\hline $15^{\text {th }}$ days & $7.30^{\mathrm{ab}} \pm 0.48$ & $7.30^{\mathrm{ab}} \pm 0.48$ & $6.90^{\mathrm{b}} \pm 0.74$ & $6.80^{\mathrm{b}} \pm 0.79$ & $7.00^{\mathrm{a}} \pm 0.67$ \\
\hline $30^{\text {th }}$ days & $7.00^{\mathrm{b}} \pm 0.67$ & $7.00^{\mathrm{b}} \pm 0.67$ & $6.40^{\mathrm{b}} \pm 0.70$ & $6.50^{\mathrm{b}} \pm 0.53$ & $6.50^{\mathrm{b}} \pm 0.53$ \\
\hline Mean & 7.33 & 7.37 & 6.97 & 6.97 & 6.97 \\
\hline CD & 0.60 & 0.54 & 0.65 & 0.58 & 0.60 \\
\hline
\end{tabular}

Note: Values are expressed as mean \pm standard deviation of three determinations.

Means within the same column followed by a common letter do not differ significantly ( $\mathrm{p} \leq 0.05)$.

Table.2 Free fatty acid content of cookies during storage period

\begin{tabular}{|l|l|}
\hline Storage period & Cookies \\
\hline $0^{\text {th }}$ days & $0.53^{\mathrm{c}} \pm 0.02$ \\
\hline $15^{\text {th }}$ days & $0.65^{\mathrm{b}} \pm 0.03$ \\
\hline $30^{\text {th }}$ days & $0.72^{\mathrm{a}} \pm 0.02$ \\
\hline Mean & 0.63 \\
\hline CD & 0.06 \\
\hline
\end{tabular}

Table.3 Free fatty acid content of muffins during storage period

\begin{tabular}{|l|l|}
\hline Storage period & Muffins \\
\hline $0^{\text {th }}$ days & $0.45^{\mathrm{c}} \pm 0.03$ \\
\hline $3^{\text {rd }}$ days & $0.55^{\mathrm{b}} \pm 0.03$ \\
\hline $6^{\text {th }}$ days & $0.63^{\mathrm{a}} \pm 0.02$ \\
\hline Mean & 0.55 \\
\hline CD & 0.06 \\
\hline
\end{tabular}

Note: Values are expressed as mean \pm standard deviation of three determinations. Means within the same column followed by a common letter do not differ significantly $(\mathrm{p} \leq 0.05)$. 
Table.4 Microbial load in baked products during storage

\begin{tabular}{|l|l|l|l|}
\hline \multirow{2}{*}{ Products } & $\begin{array}{l}\text { Storage } \\
\text { period } \\
(\text { Days })\end{array}$ & $\begin{array}{l}\text { Total bacterial count } \\
\left(\times \mathbf{1 0}^{\mathbf{3}} \mathbf{C F U}\right)\end{array}$ & $\begin{array}{l}\text { Total fungal count } \\
\left(\times \mathbf{1 0}^{\mathbf{3}} \mathbf{C F U}\right)\end{array}$ \\
\hline Cookies & $0^{\text {th }}$ day & Nil & Nil \\
\cline { 2 - 4 } & $15^{\text {th }}$ day & 1.00 & Nil \\
\cline { 2 - 4 } & $30^{\text {th }}$ day & 2.00 & 1.00 \\
\hline \multirow{3}{*}{ Muffins } & $0^{\text {th }}$ day & Nil & Nil \\
\cline { 2 - 4 } & $3^{\text {rd }}$ day & 2.00 & 1.00 \\
\cline { 2 - 4 } & $6^{\text {th }}$ day & 3.00 & 2.00 \\
\hline
\end{tabular}

Note: CFU- Colony Forming Unit

Fig.1 Mean sensory values of muffins during storage period

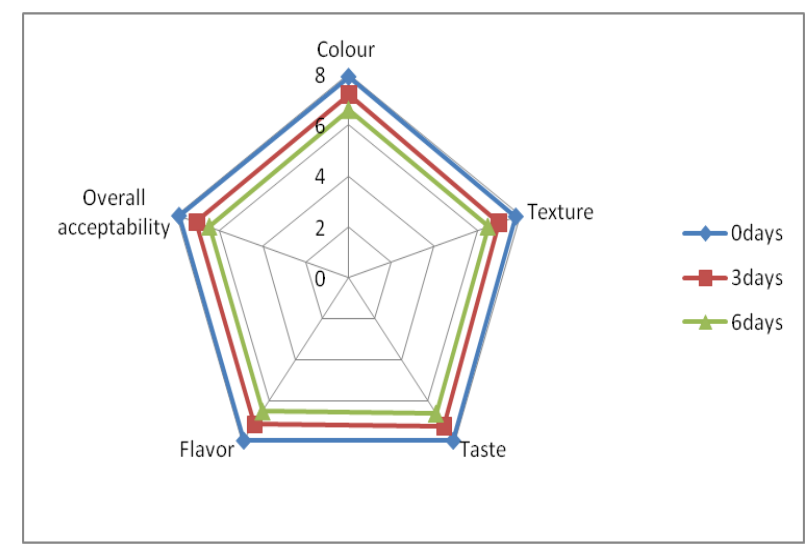

Singh et al., (2000) studied that free fatty acid content of soy-fortified biscuits and reported its increase with storage period. The increase in FFA content of soy biscuits was due to greater increase in their moisture content which promoted fat hydrolysis during storage.

\section{Microbial quality of baked products during storage}

The best accepted products from sensory evaluation were stored in polythene covers and microbial load was assessed.

In cookies the microbial count such as total bacterial count and total fungal count was observed on $0^{\text {th }}, 15^{\text {th }}$ and $30^{\text {th }}$ days. In muffins the total bacterial count and total fungal count was observed on $0^{\text {th }}, 3^{\text {rd }}$ and $6^{\text {th }}$ days the result was represented in Table 4. The increase in microbial load as the storage period lengthened might have been due to a corresponding increase in moisture content during storage period but the total load for bacterial count and fungi were within the permissible limits. This result agreed with the study reported by Nagi et al., (2012) in cereal bran incorporated biscuits.

The developed cookies with 10\% GBR for 30 days and 20\% GBR of muffins were stored for 6 days. There was a decreasing trend of sensory scores for color, texture, taste, flavor, and overall acceptability for selected bakery products, during shelf life study. In shelf life study free fatty acid content and microbial quality of the products also evaluated along with sensory evaluation. An 
increase in free fatty acid content levels with storage was observed in cookies and muffins. In cookies the bacteria colonies were observed in $15^{\text {th }}$ and $30^{\text {th }}$ days. The fungi were observed on the $30^{\text {th }}$ day of storage in cookies but in case of muffins bacteria and fungi was observed from $3^{\text {rd }}$ to $6^{\text {th }}$ day of the storage period.

\section{References}

AOCS. 1990. Official methods and recommended practices of the American oil chemists' society, $4^{\text {th }}$ ed. $2^{\text {nd }}$ printing (additions and revision through 1993). American Oil Chemists' Society Champaign IL.

Baljit, S.G., Sandra, D.D and Suresh, S.N. 2002. Lipid shortenings: a review. Food Research International. 35: 1015-1048.

Ilowefah, M., Chinma, C., Bakar, J., Ghazali, H. M., Muhammad, K and Mohammad, M. 2014. Fermented brown rice flour as functional food ingredient. Foods. 3(1): 149-159.

Nagi, H.P.S., Kaur, J., Dar, B. N and Sharma, S. 2012. Effect of storage period and packaging on the shelf life of cereal bran incorporated biscuits. American
Journal of Food Technoology. 1-10.

Obradović, V., Babić, B.J., Subarić, D., Jozinović, A. and Ačkarb, D. PhysicoPhysico-chemical Properties of Corn Extrudates Enriched with Tomato Powder and Ascorbic Acid. Chem. Biochem. Eng. Q., 29(3): 325-342.

Roy, P., Orikasa, T., Okadome, H., Nakamura, N and Shiina, T. 2011. Processing conditions, rice properties, health and environment. International Journal of Environmental Research and Public Health. 8: 1957-1976.

Singh, R., Singh, G and Chauhan, G.S. 2000. Development of soy-fortified biscuits and shelf-life studies. Journal of Food Science and Technology.37(3): 300303.

Snedecor, G.W., and Cochran, W.G. 1983. Statistical Methods. Oxford and IBH publishing company, New Delhi.

Thambekar, D.H., Murhekar, S.M., Dhanorkar, D.V., Gulhane, P.B and Dudhane, M.N. 2009. Quality and safety of street vended fruit juices: a case study of Amravati city, India. Journal of Applied Biosciences. 14: 782-787.

\section{How to cite this article:}

Mounika, B., S. Suchiritha Devi, K. Uma Maheswari and Hemalatha, V. 2017. Storage Stability of Germinated Brown Rice Incorporated Baked Products. Int.J.Curr.Microbiol.App.Sci. 6(12): 4051-4055. doi: https://doi.org/10.20546/ijcmas.2017.612.466 